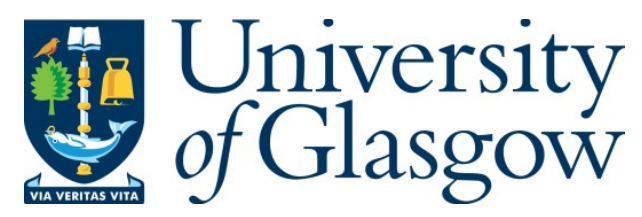

Banks, D. (2016) Scottish pioneers of tools for low temperature geothermal applications: William Cullen, the Stirling brothers and William Rankine. International Journal for the History of Engineering and Technology, 86(2), pp. 147-160.

There may be differences between this version and the published version. You are advised to consult the publisher's version if you wish to cite from it.

http://eprints.gla.ac.uk/128855/

Deposited on: 6 October 2016

Enlighten - Research publications by members of the University of Glasgow http://eprints.gla.ac.uk 


\title{
Scottish pioneers of tools for low temperature geothermal applications: William Cullen, the Stirling brothers and William Rankine
}

\author{
David Banks
}

School of Engineering, James Watt Building (South), University of Glasgow, Glasgow, G12 8QQ, UK

\begin{abstract}
The heat pump is a tool for extracting low temperature heat from the environment (e.g., from the shallow geosphere) and supplying it for space heating at a higher temperature. It is noteworthy that so much of the pioneering work that allowed the development of this tool was associated with Scottish scientists and engineers. William Cullen's experimentation led to an understanding of the transfer of latent heat (which takes place at the evaporator of the heat pump). William Rankine and the Stirling brothers worked on the thermodynamic cycles that lie at the heart of many heat pumps and low temperature heat engines. William Thomson (Lord Kelvin) first proposed the use of the heat pump for space heating and, with James David Forbes, worked on an understanding of the behaviour of heat in the ground.
\end{abstract}

\section{Introduction}

Geologically stable Britain is not blessed with readily available high-enthalpy reserves of geothermal energy. Britain does, however, possess abundant, ubiquitous reserves of very low enthalpy geothermal heat, which can be exploited by means of the ground source heat pump (GSHP). This GSHP has finally found popularity in the UK as a means of extracting low temperature heat from the earth and supplying it as space heating to residential and commercial buildings. Well over 10,000 systems are believed to be installed in the UK at present and a scientific framework of 'thermogeology'1 has evolved to support those who design and install GSHP systems. At greater depths, somewhat warmer geothermal reserves can be accessed by deep drilling ${ }^{2-4}$, which can be used for direct heat supply or even for electrical power generation using innovative low-temperature heat engines ${ }^{5}$.

It is intriguing that so many of the crucial innovations in the development of GSHP technology and thermogeology have had a Scottish connection. William Thomson (Lord Kelvin) and James David Forbes founded the science of thermogeology ${ }^{6}$, while Dr Graeme Haldane constructed one of the earliest ground source heat pump systems ${ }^{7}$. This article traces the key discoveries that allowed the development of the environmental heat pump cycle and of low temperature heat engines such as the organic Rankine cycle engine and the Stirling engine ${ }^{5}$. 


\section{Early Refrigeration}

The household fridge is a relatively new invention. It is a type of heat pump consuming external power (electricity) to move heat up a temperature gradient (from your chilled beer out into the kitchen). It is therefore identical in concept to a ground source heat pump - which consumes external power (electricity) to move heat from the cool earth to a warm interior space.

Refrigerators became common household appliances only after the First World War, allowing households to store perishable fresh dairy produce, meats and fish with scarcely a second thought. Up until then, refrigeration had largely been available via ice-boxes: unless clean ice could be obtained locally, it was imported from the eastern seaboard of the USA, the Greenland Seas or Scandinavia and distributed in British towns by an 'ice-man' 8,9,10. Artificial refrigeration had long been a 'holy grail' of engineering ${ }^{11}$, finally attained by the American Jacob Perkins, working in London in 1835 (Figure 1)12,13, 14.

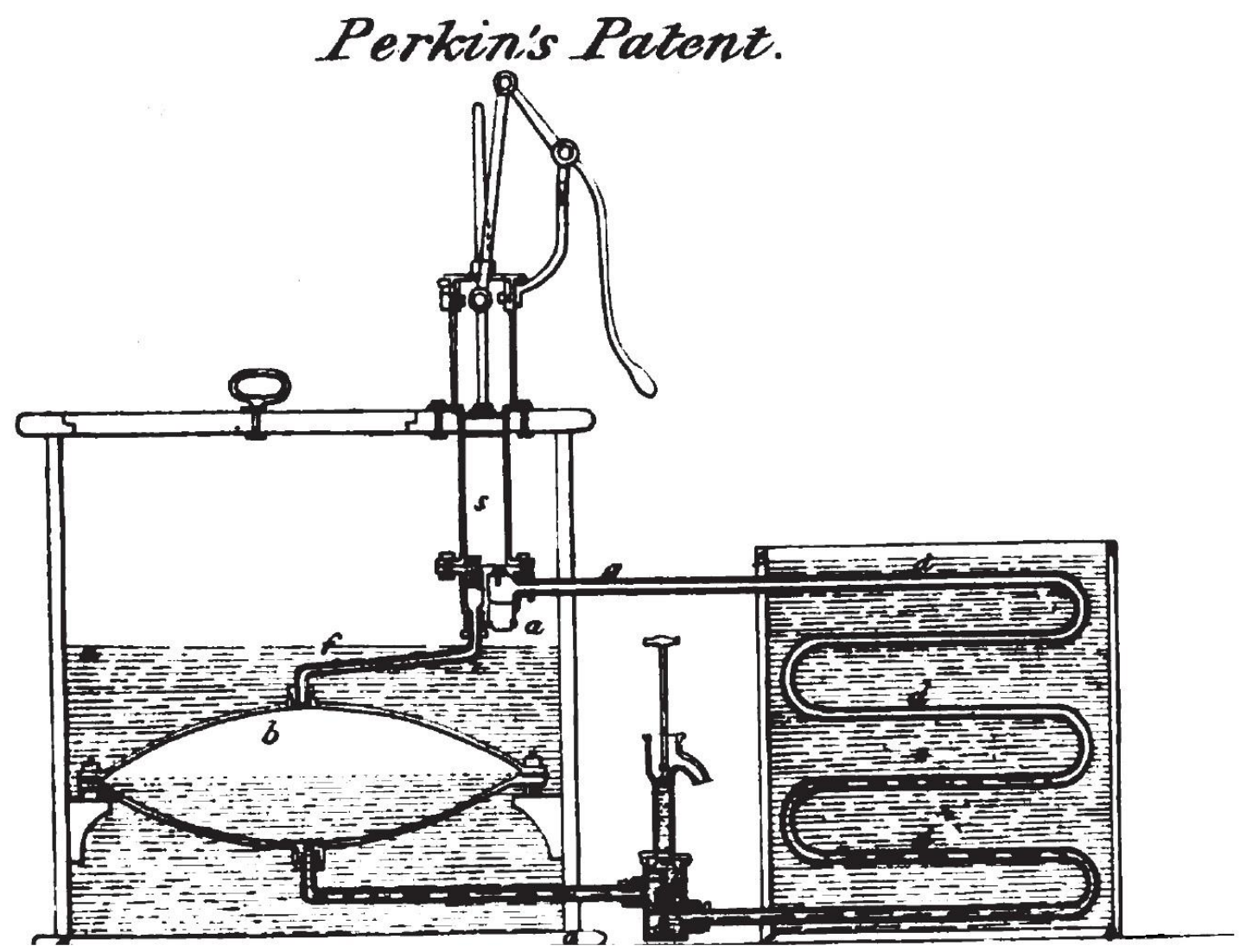

Figure 1. The drawing accompanying Perkin's patent for a device for producing ice and cooling fluids, sealed 14th August 1835: believed to be the first artificial refrigerator based on a vapour compression cycle. From J.S. Hodson (1837) ${ }^{12}$, believed to be out of copyright.

The heat pump is the thermodynamic 'reverse' of a heat engine. The latter uses the 'flow' of heat down a temperature gradient (e.g. from hot combustion gases to a low temperature exhaust in an internal combustion engine, or from high temperature steam to a low temperature condensate in a steam engine) to perform mechanical work. The heat pump applies mechanical work (e.g. via an 
electrically or mechanically powered compressor) to move heat up a temperature gradient.

The functioning of most heat pumps and many heat engines is dependent on two fundamental physical principles:

1) When a fluid or gas is compressed adiabatically (without external heat exchange), it generally heats up. When a fluid expands, it generally cools down (the heat content becomes less 'concentrated' in simple terms). For gases, the processes are generally covered by the Ideal Gas Law, where $P$ is pressure, $V$ is volume, $T$ is absolute temperature, $R$ is the Universal Gas Constant and $n$ is number of moles of gas.

$P V=n R T$

and by other equations depending on the nature of the expansion or contraction, for example:

- For reversible isentropic adiabatic expansion and compression of ideal gas

$$
\frac{T_{2}}{T_{1}}=\left(\frac{P_{2}}{P_{1}}\right)^{\frac{\gamma-1}{\gamma}}=\left(\frac{V_{1}}{V_{2}}\right)^{(\gamma-1)}
$$

where $\gamma=C_{P} / C_{V} ; C_{P}$ and $C_{V}$ are the specific heat capacities at constant pressure and constant volume, respectively,

- The Joule-Thomson effect (named after James Prescott Joule and William Thomson, Lord Kelvin) ${ }^{15}$ for the continuous expansion of a fluid flow through a valve or porous plug, and of particular importance to refrigeration and heat pump cycles.

$\left(\frac{\partial T}{\partial P}\right)=\frac{V}{C_{P}}(\alpha T-1)$

where $\alpha=$ coefficient of thermal expansion of gas. $(\partial T / \partial P)$ is usually (but not always) positive at typical temperatures and expansion results in cooling. William Rankine ${ }^{16}$ identified the Joule-Thomson effect as isenthalpic.

Thus, the temperature of a working fluid can be increased (or decreased) without the application of a heat source, merely by performing mechanical work in compression (or a mechanical expansion).

2) The fact that, when a liquid evaporates, it must absorb a certain quantity of heat (the latent heat of vaporisation), simply to change phase from a liquid to a gas. When it condenses, it releases this latent heat. This latent heat is quite substantial, for water it is $2260 \mathrm{~kJ} \mathrm{~kg}^{-1}$, compared with a specific heat capacity of only $4.2 \mathrm{~kJ} \mathrm{~kg}^{-1} \mathrm{~K}^{-1}$.

In most modern heat pumps, the evaporation of a cold refrigerant is used to absorb heat from a heat source (e.g. the ground). The refrigerant is then mechanically compressed to raise its temperature. It is then allowed to condense 
and shed its heat load to a point of use that requires heating (e.g. a central heating system), before expanding through a valve (i.e. the Joule-Thomson ${ }^{15}$ effect, above). Two Scottish scientists were instrumental in investigating and systematising these steps - William Cullen and William Rankine.

\section{William Cullen (1710-1790)}

William Cullen was a Professor at Edinburgh Medical School. He was born in Hamilton, Lanarkshire and was schooled at Hamilton Academy (then the Old Grammar School). He studied at both Glasgow and Edinburgh Universities between 1726 and 1736, and gained experience as a ships' medic and an assistant apothecary. He opened his first medical practice in Edinburgh in 1736. In 1744, he moved with his family to Glasgow and commenced teaching chemistry and medicine at the University, eventually being awarded a Professorship in Medicine in 175117,18. In 1755, he moved back to Edinburgh to take up a Professorship of Chemistry and Medicine there. He immediately started investigating the effects of evaporation of various volatile liquids on temperature.

We all know that, if you spill vodka on your skin, it produces a cooling sensation as it evaporates. One of Cullen's students appeared suspiciously familiar with this principle and Cullen's treatise on the topic begins, "A Young Gentleman, one of my pupils....observed to me, that, when a thermometer had been immersed in spirit of wine... upon taking the thermometer out of the spirit and suspending it in the air, the mercury in the thermometer always sunk two or three degrees [Fahrenheit]". Cullen continued this (probably late-night) experimentation with brandy and concluded that, "by repeated dippings, the cold produced might be rendered very remarkable": indeed Cullen obtained sub-freezing temperatures by this method. He continued to experiment with other fluids, including the volatile tincture of sulphur and oil of pimento, and decided that "the cold produced is the effect of evaporation"19.

Cullen also played around with placing thermometers into evacuated chambers. He came tantalisingly close to discovering the cooling effects of expansion: when experimenting with his vacuum pump he found that "a thermometer hung in the receiver of an air pump always drops two or three degrees upon the air's being exhausted. After a little time, the thermometer in vacuo always returns to the temperature of the air in the chamber and, upon letting air again into the receiver, the thermometer always rises two or three degrees above the temperature of the external air"19.

It was in 1756 that he built a device to produce artificial refrigeration. His device used a vacuum pump to lower air pressure, allowing a vessel of ether (or other volatile fluid) to boil, absorbing latent heat (see above) and dropping the temperature of the vessel considerably - enough to produce a crust of ice around the vessel ${ }^{19}$. It was possibly the first time that refrigeration had been artificially produced, although many traditional societies had worked out that cold could be produced simply by allowing natural water to evaporate away from porous surfaces, or by using freezing mixtures of salts such as nitre ${ }^{1,8,10,11}$ ). Cullen's 
pioneering work was furthered to produce functioning refrigeration devices by, for example, John Leslie ${ }^{11}$.

Beyond the sciences, Cullen was a familiar of David Hume and Adam Smith. He died in 1790 and is buried in Kirknewton, near Edinburgh.

\section{Carnot, Stirling and the heat engine / pump cycle}

The fact that heat and steam could be used to do work had been exploited even before Thomas Newcomen built his first steam engine in around 1712 (for a history of the steam engine, see Rankine's magnum opus ${ }^{20}$ of 1859). The heat engine was refined by the Scot, James Watt (born in Greenock and initially working at the University of Glasgow), in the period 1765-1776, resulting in a more efficient engine design with a separate condenser.

It was a Frenchman, however, who first considered the theory behind heat engines. Nicolas Léonard Sadi Carnot published his Reflections on the Motive Power of Fire 21 in 1824, aged only 28. He concluded that "the production of motive power is then due in steam engines not to an actual consumption of caloric [heat] but to its transportation from a warm body to a cold body". He also identified that there is a maximum theoretical efficiency for any heat engine, for given operating temperatures, and outlined his concept of a frictionless ideal heat engine, where there was no leakage of heat through any of its components. This ideal heat engine concept is still referred to today as the Carnot Cycle. Figure 2 shows an idealised Carnot cycle graphically on a PV diagram. It comprises, 4 stages: (i) isentropic heating A-B; (ii) isothermal expansion at a high temperature $\mathrm{T}_{2} \mathrm{~B}-\mathrm{C}$; (iii) isentropic cooling $\mathrm{C}$-D and (iv) isothermal compression at low temperature $\mathrm{T}_{1} \mathrm{D}-\mathrm{A}$.

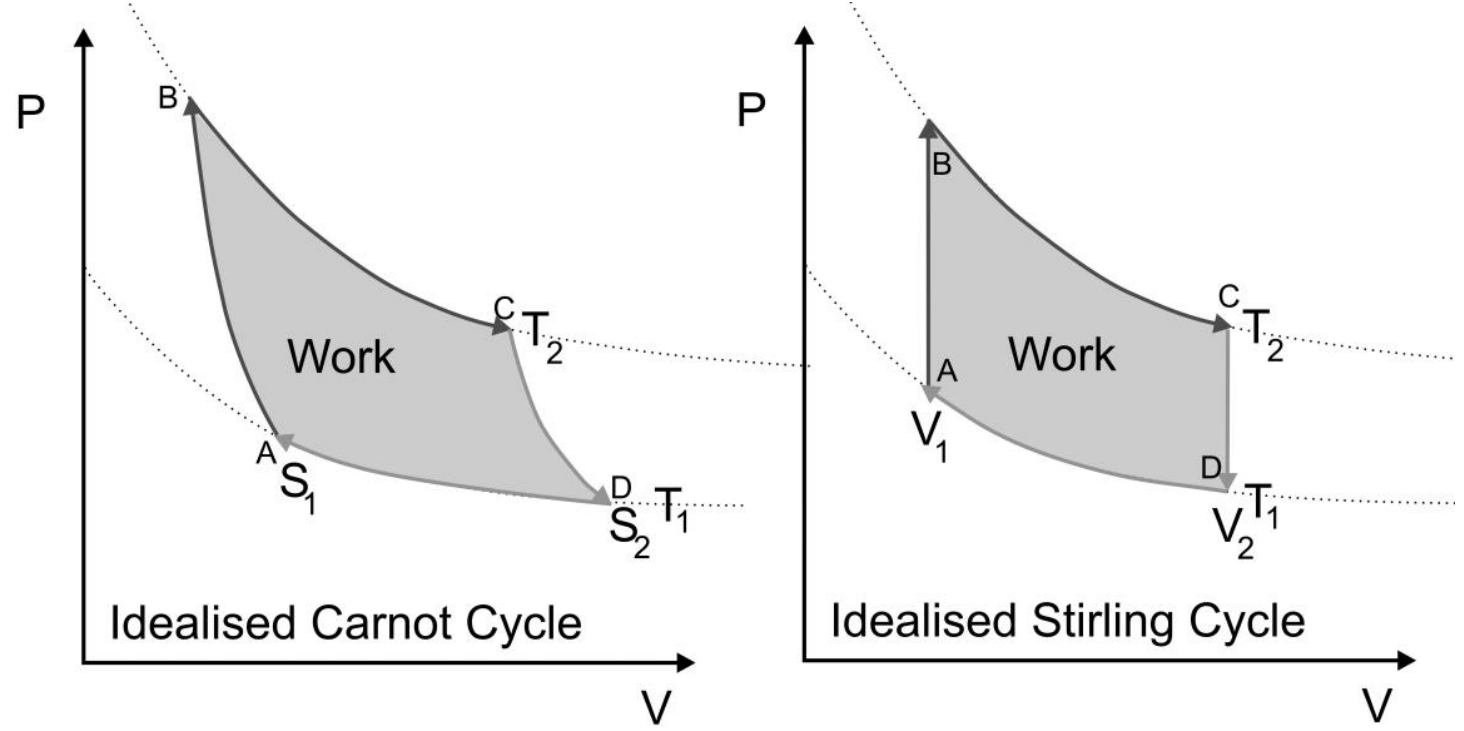

Figure 2. Idealised single phase Carnot and Stirling Cycles, plotted on Pressure (P) versus Volume (V) diagrams. The dotted lines are hyperbolae 
representing isotherms at low and high temperatures $T_{1}$ and $T_{2}$. In the Carnot cycle, the heating $(A B)$ and cooling (CD) phases are isentropic, while in the Stirling Cycle they are isochoric (constant volume). The area enclosed by the cycle represents the maximum work extractable from the cycle.

Carnot's insight was reworked and built upon by subsequent workers, such as:

- Benoît Paul Émile Clapeyron (1799-1864), who articulated Carnot's cycle in terms of PV diagrams (Figure 2).

- Julius von Mayer and James Prescott Joule, who overturned the consensus that heat is a conservative quantity and demonstrated that heat and work are equivalent (Joule's papers of 1843 and $1850^{22,23}$ were based on papers first read to the Meetings of the British Association for the Advancement of Science in 1843 and 1845 in Cork and Cambridge).

- Rudolph Clausius (1822-1888), who progressed work on the mechanical equivalence of work and heat (1850), developed the concept of entropy (1865) and who made major steps forward in the kinetic theory of gases.

Sadi Carnot's Theorem that heat engines have a maximum efficiency, related to the temperature difference between source and sink, only reached its modern form (below) after James Prescott Joule (in an informal letter to William Thomson in 1848) and Rudolph Clausius in 1850 qualified this statement by inferring that the maximum efficiency $\eta_{\max }$ was inversely proportional to source temperature ${ }^{24}$ :

$\eta_{\max }=\frac{T_{H}-T_{C}}{T_{H}}$

where $T_{H}$ and $T_{C}$ are the absolute temperatures of the hot source and cold sink, respectively (William Rankine ${ }^{16}$ cited exactly this formulation in 1854). Parallel with this was the realisation that, as heat flows 'downhill' through an engine, a proportion of the heat is converted to work.

The corollary of this is that there is a maximum heat pump efficiency:

$\eta_{\max }=\frac{T_{H}}{T_{H}-T_{C}}$

where $\mathrm{T}_{\mathrm{H}}$ and $\mathrm{T}_{\mathrm{C}}$ are the absolute temperatures of the hot sink and the cool source (respectively). The actual (as opposed to the theoretical maximum) efficiency of a heat pump is often referred to as its Coefficient of Performance (CoP).

\section{Robert Stirling (1790-1878) and James Stirling (1800-1876)}

The Rev. Dr. Robert Stirling (1790-1878), was born in Methven, Perthshire, Scotland and studied at the Universities of Glasgow and Edinburgh, before 
becoming 'licensed to preach' in 1815 and awarded a post of Minister, 2nd Charge, in Kilmarnock in $1816^{25}$. It is remarkable that, in the same year (1816), seemingly out of the blue, he filed patents for a 'heat economiser' applied to a hot air engine (i.e. what has become known as a 'Stirling Engine'). The background to his invention is unclear, but it becomes a little more understandable when we remember that the patent was based on practical experimentation, presumably either at the University of Glasgow or Edinburgh. We should also remember that (a) Scottish students were able to cover a wide ranging syllabus including divinity, logic, mathematics, ancient languages and science, (b) one of Stirling's University teachers at Edinburgh was probably John Leslie, who worked on conduction and radiation of heat and developed an impressive ice machine ${ }^{11}$ based on an air pump and William Cullen's principles, and (c) that the principles of the air engine were already known in outline. It was probably in Thomas Morton's workshops in Kilmarnock that Stirling built his first full-scale engine to pump water from a local stone quarry in 1818. Around this time he also presented two 29-inch high experimental engines to the Universities of Edinburgh and Glasgow ${ }^{25}$. The Edinburgh engine was used as a demonstration model by Professor John Leslie, while the Glasgow engine was eventually unearthed by William Thomson, Lord Kelvin ${ }^{26}$.

The 'Stirling engine' was an alternative to the steam engine. It employed the repeated compression and expansion of air, using the heat flow between a warm source and a cool sink, to provide motive power ${ }^{27-29}$. Stirling's major innovation (in his 1816 patent) was a 'heat economiser' or 'regenerator': an efficient dynamic heat exchanger providing thermal capacitance or storage and keeping the warm and cold compartments of the engine thermally separate. His application of this principle to the air engine and also some of the phase-shifting linkages employed in the engine can also be regarded as novel, however ${ }^{25}$. Stirling's motivation appears to have been to achieve fuel economy: indeed, there were already voices warning of complacency over cheap, abundant coal $^{30}$.

In 1824 Robert moved to Galston, Ayrshire, where he remained until his death, to take up a position as church minister. It seems that he always prioritised the church over engineering in his career, although he often pottered in an engineering workshop at night at his Galston Manse, and he founded a dynasty of locomotive engineers through his sons Patrick, William and James ${ }^{25}$. Robert's younger brother, James, also studied at University, but opted for engineering rather than the Church as his preferred career. It was this brother, James, who set about up-scaling and improving Robert's engine, by applying water cooling to the 'cold' side of the engine and also by utilising compressed air. In 1827-8, he constructed a, rather inefficient, $20 \mathrm{Hp}$ engine at Girdwood's foundry in Glasgow $^{25}$. In 1830, he moved to the Dundee Iron Foundry in Whale Lane, and initially constructed a small 2 to $2.5 \mathrm{Hp}$ prototype ${ }^{27}$, running at $360 \mathrm{psi}$. He later built a larger $21 \mathrm{Hp}$ engine to power machinery at the Foundry and, finally, in 1842, a 40-45 Hp engine ${ }^{25,31}$, which ran for 5 years before being decommissioned due to the repeated failure of the heated expansion vessel to withstand the fires of the furnace. 
Robert Stirling met William Thomson (Lord Kelvin) and his brother James Thomson. The latter was left with a firm impression that, while Stirling's engine worked, Robert did not understand the fundamental principles and imagined he had invented something akin to perpetual motion ${ }^{25}$. William Thomson recognised that the Stirling Engine could be reversed to produce a primitive heat pump $^{26}$. It was left to William Rankine to flesh out a full description of the Stirling thermodynamic cycle ${ }^{20}$ and of the 'heat economiser'32. The Stirling cycle is potentially equally as efficient as the Carnot Cycle, but employs (in idealised form) two isochoric (equal volume) phases and two isothermal phases (Figure 2). The lack of heat leakage and 'messy' components such as condensers and turbines in the Stirling Engine leads to potentially very high real-life efficiencies and has led to its popularity in modern times. Modern Stirling Engines are very safe and can run off relatively small temperature differentials and at low temperatures, rendering them attractive in connection with geothermal resources of modest temperature ${ }^{5,27-29}$. Research into flat-plate, low temperature-differential Stirling engines has been particularly associated with Ivo Kolin's group in the former Yugoslavia, with prototypes being presented as early as 1983. Applications have been being considered for the 'Mladost' geothermal field near Zagreb, with water temperatures of $80^{\circ} \mathrm{C}$ and yield of some $58 \mathrm{~L} / \mathrm{s}$. Efficiencies would be greatest in winter (greatest temperature differential available), and Kolin's team have estimated a potential electrical power generation capacity of $4.3 \mathrm{MW}^{5}$. Currently, however, the major commercial difficulty seems to be the practical up-scaling and high construction cost of low temperature Stirling engines. Units of only a few $\mathrm{kW}_{\mathrm{e}}$ generation capacity have been constructed and demonstrated, with current trials taking place in the range a few tens of $\mathrm{kW}_{\mathrm{e}}$.

\section{William John Macquorn Rankine (1820-1872)}

William Rankine (Figure 3) was born in 1820 in Edinburgh to David Rankine (an engineer and military officer) and Barbara Grahame, and was thus a contemporary of William Thomson, Lord Kelvin ${ }^{6}$. His elder brother died as a child and William was raised and educated largely at home, as a rather sickly only child. He was 'turned on' to physics at the age of 14 by Newton's Principia and studied science at Edinburgh University between 1836 and 1838. At Edinburgh, he studied under Prof. John David Forbes ${ }^{6}$, a pioneer in heat theory and an early thermogeologist ${ }^{33}$. Rankine did not complete his degree, leaving to practice engineering, firstly with his father on the Edinburgh and Dalkeith Railway and then as apprentice to the engineer John Benjamin MacNeill. Both at University and in employment, William won prizes for his essays and papers. Rankine was appointed Professor of Engineering at Glasgow University in 1855 and his inaugural lecture addressed the importance of bridging the divide between theory and practice in engineering and science (a topic which admirably reflects his own background as a practitioner).

Rankine was a keen musician, playing cello and piano. He composed poems, songs and fables ${ }^{34}$, of which most people's favourite is entitled 'A Mathematician in Love' and contains the following verses: 
Let $\mathrm{x}$ denote beauty, - $\mathrm{y}$, manners well-bred,-

$\mathrm{z}$, Fortune, - (this last is essential),

Let L stand for love - our philosopher said,

Then $\mathrm{L}$ is a function of $\mathrm{x}, \mathrm{y}$, and $\mathrm{z}$,

of the kind which is known as potential.

Now integrate $\mathrm{L}$ with respect to $\mathrm{dt}$

(t Standing for time and persuasion);

Then, between proper limits, 'tis easy to see,

The definite integral Marriage must be :-

(A very concise demonstration).

Rankine can't let the poem be, without providing a summary in the form of an integration demonstrating that Love has an inverse relationship to the deviation of the Beloved from some ideal of Beauty, Manners and Fortune:

$L=\phi(x, y, z)=\iiint \frac{f(x, y, z)}{\sqrt{(\xi-x)^{2}+(\eta-y)^{2}+(\zeta-z)^{2}}} d \xi d \eta d \zeta$

and $\int_{-\infty}^{+\infty} L d t=M$, where $M=$ marriage

If the thought of marriage lasting from minus eternity to plus eternity sends shivers down your spine, be reassured. It turns out that the Lady's affections do not care a fig for the cold logic and calculus of the Mathematician, and she runs off "with a dashing dragoon". 


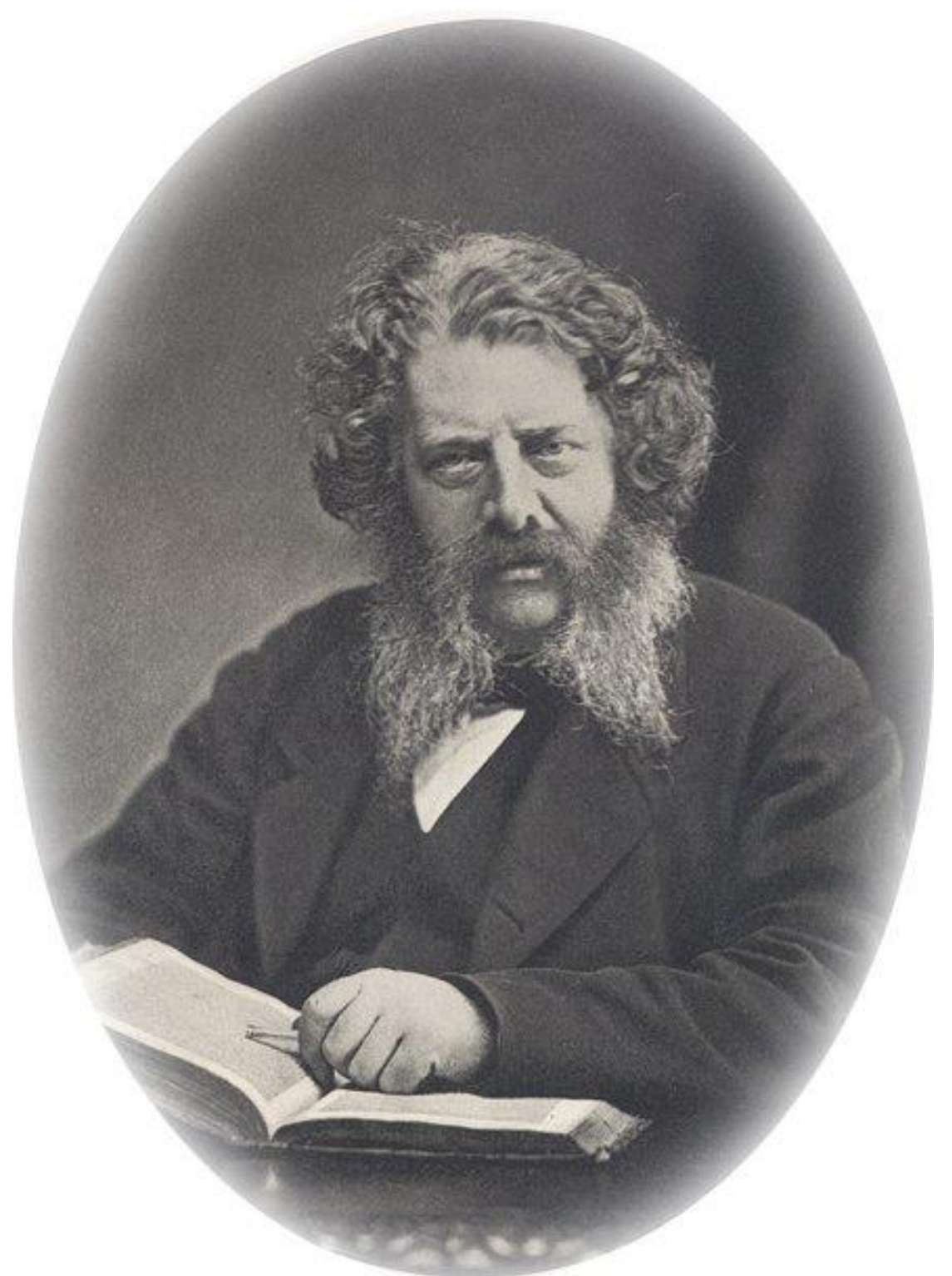

Figure 3. William Rankine, from a portrait in MacLehose's (1886) book ${ }^{35}$. Image believed to be out of copyright.

Rankine's interests were highly applied and wide-ranging. He published numerous papers on geotechnical and soils engineering ${ }^{36}$. He was one of the earliest workers in this field, his most enduring work relating to soil pressures behind retaining walls. The British Geotechnical Association established an Annual Rankine Lecture from 1961 in his honour, the inaugural lecture being delivered by Arthur Casagrande. A pleasing circularity was attained in 2001 when the lecture first addressed a thermogeological topic: Prof. $\mathrm{H} \mathrm{Brandl}^{37}$ spoke on "Energy foundations and other thermo-active ground structures". Rankine is probably best remembered, however, for his theoretical work on heat and applying it to real engineering problems. He appreciated early on that many thermal phenomena could be attributed to molecular motion; he distinguished clearly between actual (sensible) and latent heat ${ }^{16}$; he was largely responsible introducing the concepts of energy and energetics to thermodynamics. In 1859, he proposed an absolute temperature scale to rival Kelvin's, but (ever an opponent to the metric system ${ }^{34}$ ) he proposed Fahrenheit as the unit of 
subdivision. He was able to apply graphical techniques (Figure 4) to describe the thermodynamic cycle of a practical steam engine (the Rankine cycle), which encompasses the phase change from water to steam and comprises 5 elements:

- the rapid compression of water (A-B on Figure 4)

- the isobaric application of heat to raise the temperature of water to its boiling point (the liquidus, Point B')

- the continued isobaric application of heat to convert water to steam at a constant temperature ( $\left.\mathrm{B}^{\prime}-\mathrm{C}\right)$

- the steam is allowed to depressurise , approximately isentropically, via a turbine, releasing work (C-D).

- isobaric passage of steam through condenser, returning to the fluid to saturated water vapour (D-A).
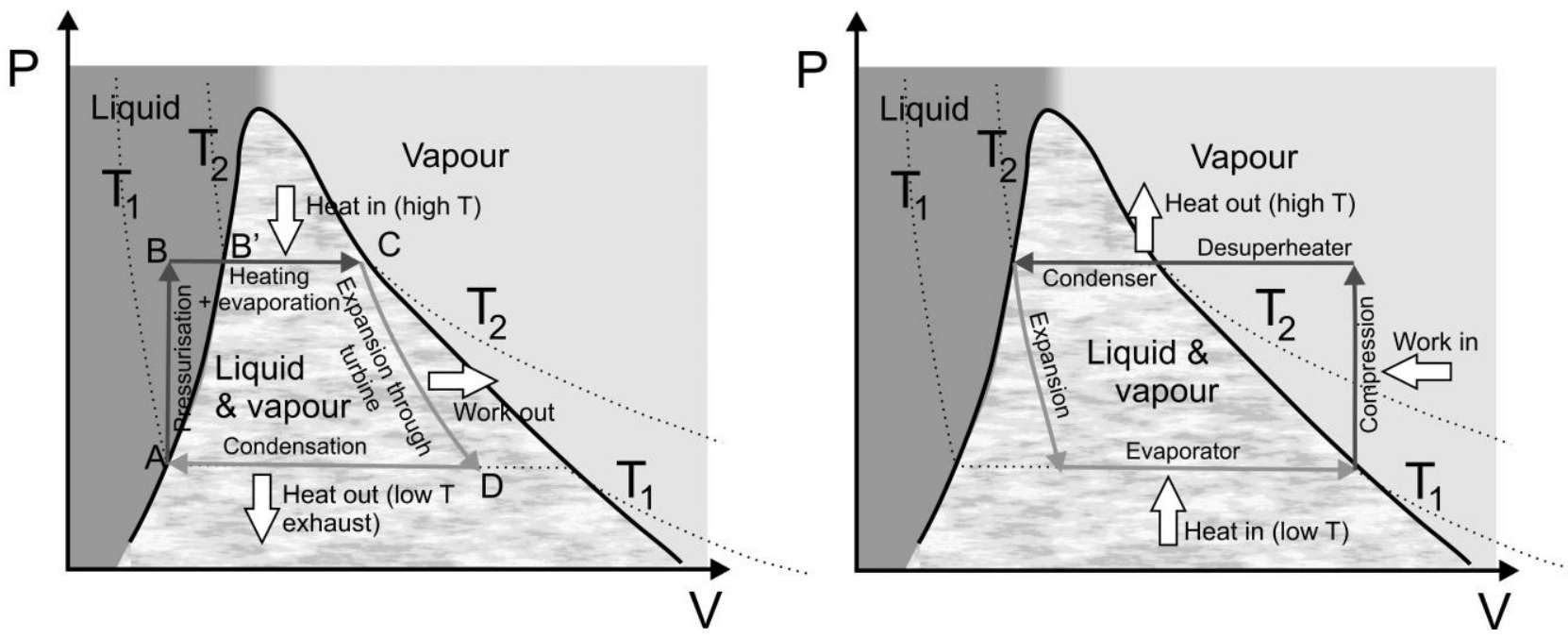

Figure 4. Idealised (left) forward and (right) reverse two-phase Rankine Cycle on pressure $(\boldsymbol{P})$-volume $(\boldsymbol{V})$ diagrams. The diagrams thus represent an idealised steam engine (left) and an idealised vapour-compression heat pump (right). The solid black line represents the liquidus, with the working fluid's critical point at its apex. In these two-phase diagrams, the isotherms are flat when liquid is being converted to vapour at constant temperature $(T)$ and pressure in an evaporator or condenser.

The theoretical cycle is less efficient than the ideal Carnot cycle (Step B-B' is not at the maximum temperature $\mathrm{T}_{2}$ ), but is a highly practical one, capable of achieving very acceptable efficiencies.

\section{The legacy of William Rankine's work for geothermal energy}

The working fluid in the Rankine thermodynamic cycle does not have to be steam and, indeed, the Organic Rankine Cycle or ORC (using, e.g., pentane or toluene) can be used to generate electricity from low temperature geothermal resources in so-called 'binary' systems (where the 'working fluid' in the turbinecondenser circuit is separated from the natural geothermal fluid by a heat exchanger). At least 258 ORC power stations are in operation globally today (many in the USA), of which the majority are based on biomass, but of which 55 
are geothermal (accounting for $10 \mathrm{MW}_{\mathrm{e}}$ generation capacity) ${ }^{38}$. Binary systems can be used to produce electricity from low-temperature geothermal resources at temperatures in the region of $120-180^{\circ} \mathrm{C}$. The International Energy Agency Energy indicates that binary plants can be made to work (though not necessarily economically) at temperatures as low as $73^{\circ} \mathrm{C}^{39}$. Possibly one of the most famous geothermal ORC plants is that of Soultz-sous-Forêts in France ${ }^{40}$ - an 'enhanced geothermal reservoir' system in granitic bedrock based on boreholes drilled to c. $5 \mathrm{~km}$. Production temperatures are in the range $150-160^{\circ} \mathrm{C}$ and the capacity of the isobutane-based ORC plant is $1.5 \mathrm{MW}_{\mathrm{e}}$.

If we reverse any of the heat engine cycles in Figures 2 and 4, we obtain a heat pump. Indeed, it was William Thomson, Lord Kelvin, who first proposed, in 1852, the use of a reverse heat engine cycle to heat buildings ${ }^{6,41}$ (possibly based on his 1847 consideration of reversing Robert Stirling's engine ${ }^{26}$ ). The cycle used in most modern vapour compression refrigerators and ground source heat pumps approximates closely to a reversed Rankine cycle. The reversed Rankine heat pump cycle neatly marries the discoveries of Cullen (evaporation and condensation to transfer heat) and Joule-Thomson (cooling of refrigerant on expansion through a throttle).

Rankine died in his early 50s, in 1872, in Glasgow. He was succeeded in the Engineering Chair at Glasgow University by Lord Kelvin's elder brother, James Thomson ${ }^{6}$. Rankine's obituary listed him as the author of Manuals on Applied Mechanics, Steam Engines and other Prime Movers, Machinery and Millwork, Civil Engineering and Shipbuilding. Rankine's reputation was not uncontroversial; both William Thomson and subsequent reviewers ${ }^{42}$ have regarded him as both verbose and a bit of a theoretical lightweight, though Thomson ${ }^{43}$ acknowledges his key contributions in his paper on thermodynamics. A more recent and positive opinion by Cook $^{44}$ acknowledges Rankine "as one of the great pioneers ... to bring the powerful resources of mathematics and physical science to the practical problems of the engineer... Rankine embodied in himself that extremely rare if not unique combination of a professional engineer of wide experience, a mathematician and physicist of the greatest distinction."

\section{The Future of Geothermal Energy in Britain}

In the wake of the 1970s oil crisis, a significant amount of geothermal research was undertaken in Britain in the early 1980s, including ${ }^{1,3}$ :

- a $1.8 \mathrm{~km}$ deep geothermal well to the deep Sherwood Sandstone aquifer in Southampton, with $>1 \mathrm{MW}_{\text {th }}$ direct heating capacity, producing groundwater at around $76^{\circ} \mathrm{C}$.

- several $>2 \mathrm{~km}$ 'hot dry rock' boreholes in granite at Rosemanowes quarry in Cornwall, with bottom-hole temperatures of $90-100^{\circ} \mathrm{C}$ but with reservoir temperatures of $55-70^{\circ} \mathrm{C}$.

The Southampton borehole was exploited, but the heat and water yields were modest. However, given that the hole was drilled in a hydrogeologically marginal 
portion of the Sherwood Sandstone of the Wessex Basin, it gave great grounds for optimism that higher-yielding and warmer wells could be drilled further west. The temperatures obtained at Rosemanowes were too low to be utilised, but it was clear that the technology was feasible and that exploitable resources could be obtained by somewhat deeper drilling. By that time, however, the oil crisis had receded and motivation for further work had diminished.

It was not until the mid-2000s that a geothermal market began to flourish in the UK again. Rising domestic and commercial gas and oil bills stimulated interest in ground source heat pumps, to supply space heating, cooling and domestic hot water from very low temperature shallow geothermal resources $\left(<20^{\circ} \mathrm{C}\right)$. At the same time, deep drilling began to be undertaken, with new boreholes being drilled at Eastgate 4 in Weardale (995 m deep, 2004), central Newcastle (1821 m, 2011) ${ }^{3}$. Several feasibility studies are being undertaken in the deep Sherwood Sandstone basins of Wessex, Cheshire, East Yorkshire/Lincolnshire and Northern Ireland. Companies have been formed to re-explore the 'hot dry' resources of the Cornish granites at 4-5 km depth, and there are even glimmers of renewed interest in the Scottish granites ${ }^{2,3}$. Paul Younger ${ }^{3}$ and his colleagues have also flagged up the geothermal potential of formation waters extracted from the North Sea hydrocarbon fields $\left(89-128^{\circ} \mathrm{C}\right)$.

It seems clear that Britain is not blessed with the high-enthalpy geothermal resources that can be exploited using conventional steam turbines or thermodynamic cycles. To make use of the very low and low enthalpy resources that are found at realistic depths in Britain (i.e. $7-180^{\circ} \mathrm{C}$ ), we need to make use of the key technologies described in this paper and pioneered by our Scottish heroes:

- the ground source heat pump ${ }^{1}$, usually containing a reverse Rankine cycle of refrigerant, an expansion valve employing the Joule-Thomson effect, and the evaporation/condensation effects documented by William Cullen and his students. This can be used to perform space heating and cooling using ground temperatures in the range $0-40^{\circ} \mathrm{C}$. This technology can also applied to the huge volumes of water stored in Britain's flooded, abandoned mines ${ }^{2}$.

- Binary power plants, such as those employing the Organic Rankine Cycle, which can potentially be used to generate electricity from resources in the range $73-180^{\circ} \mathrm{C}$.

- In the future, maybe even low temperature Stirling Engines, which can be used to generate power from resources at temperatures of $80^{\circ} \mathrm{C}$ or even lower5.

\section{References}

1 D. Banks, An Introduction to Thermogeology - Ground Source Heating and Cooling. 2nd edition (Chichester: Wiley, 2012), 544 pp.

2 A. Harber, 'Study into the potential for deep geothermal in Scotland', by AECOM Energy (Edinburgh: The Scottish Government, 2013), 
3 P.L. Younger, J.G. Gluyas \& W.E. Stephens, 'Development of deep geothermal energy resources in the UK', Proceedings of the Institution of Civil Engineers Energy 165 (2012), pp. 19-32. doi: 10.1680/ener.11.00009.

${ }^{4}$ D.A.C. Manning, P.L. Younger, F.W. Smith, J.M. Jones, D.J. Dufton \& S. Diskin, 'A deep geothermal exploration well at Eastgate, Weardale, UK; a novel exploration concept for low-enthalpy resources', Journal of the Geological Society of London 164/2 (2007), pp. 371-382. doi: 10.1144/0016-76492006-015

5 I. Kolin, S. Koscak-Kolin \& M. Golub, 'Geothermal electricity production by means of the low temperature difference Stirling engine', Proceedings of the World Geothermal Congress 2000, Kyushu-Tohoku, Japan, 28 ${ }^{\text {th }}$ May $-10^{\text {th }}$ June (2000), pp. 3199-3203.

6 D. Banks, 'William Thomson - father of thermogeology', Scottish Journal of Geology 51/1 (2015), pp. 95-99. doi: 10.1144/sjg2013-017

7 D. Banks, 'Dr T.G.N. 'Graeme' Haldane - Scottish heat pump pioneer', The International Journal for the History of Engineering \& Technology 85/2 (2015), pp. 168-176. doi: 10.1179/1758120615Z.00000000061

8 T. Masters, The Ice Book, being a compendious and concise history of everything connected with ice, from its first introduction into Europe as an article of luxury to the present time, with an account the artificial manner of producing pure and solid ice and a valuable collection of the most approved recipes for making water ices and ice creams at a few minutes notice, (London: Simpkin, Marshall \& Co., 1844).

${ }^{9}$ E. O’Neill, The Iceman Cometh (New York: Random House, 1946).

${ }^{10}$ G. Weightman, The Frozen Water Trade (London: Harper Collins, 2003).

11 J. Leslie, A Short Account of Experiments and Instruments Depending on the Relations of Air to Heat and Moisture, (Edinburgh: William Blackwood \& others, 1813), 178 pp. See especially pp. 7-10, 47-48, 138-178.

12 J.S. Hodson, Repertory of Patent Inventions and Other Discoveries and Improvements in Arts, Manufactures and Agriculture. New series, Volume 7. (London: J.S. Hodson, 1837).

13 F. Bramwell, 'Ice-making', Journal of the Society of Arts 31/1568 (1882), pp. 76-77.

14 J.A. Ewing, The Mechanical Production of Cold, $2^{\text {nd }}$ edition (Cambridge: Cambridge University Press, 1921), pp. 82-83.

15 W. Thomson \& J.P. Joule, 'On the thermal effects of fluids in motion', Philosophical Transactions of the Royal Society of London 143 (1853), pp. 357365.

16 W.J.M. Rankine, 'On the geometrical representation of the expansive action of heat, and the theory of thermo-dynamic engines', Proceedings of the Royal Society of London 6 (1854), pp. 388-392, and, in expanded version, Philosophical Transactions of the Royal Society of London 144, pp. 115-175. 
$17 \mathrm{~J}$. Thomson, An Account of the Life, Lectures and Writings of William Cullen, M.D. Volume 1 (Edinburgh: William Blackwood, 1832).

$18 \mathrm{~J}$. Thomson, An Account of the Life, Lectures and Writings of William Cullen, M.D. Volume 2 (Edinburgh: William Blackwood, 1859).

19 W. Cullen, 'An Essay on the Cold Produced by Evaporating Fluids and of some other Means of Producing Cold', published as an appendix to Experiments upon Magnesia Alba, Quick-Lime and other Alcaline Substances by J. Black (Edinburgh: William Creech, 1777). Originally read and published in 1756. See especially pp. $115,128,131-132$.

20 W.J.M. Rankine, A Manual of the Steam Engine and Other Prime Movers (Glasgow: Richard Griffin \& Co., 1859), 575 pp.

${ }^{21}$ N.L.S. Carnot, Réflexions sur la Puissance Motrice du Feu (Paris: Bacelier, 1824). Translated by R.H. Thurston, Reflections on the Motive Power of Heat (New York: John Wiley \& Sons, 1897).

22 J.P. Joule, 'On the calorific effects of magneto-electricity, and on the mechanical value of heat', Philosophical Magazine (Series 3) 23/152 (1843), pp. 263-276.

23 J.P. Joule, 'On the mechanical equivalent of heat', Philosophical Transactions of the Royal Society of London 140 (1850), pp. 61-82.

24 D. Lindley, Degrees Kelvin: A Tale of Genius, Invention and Tragedy (Washington D.C.: National Academies Press, 2004), 392 pp. See especially p. 104.

25 R. Sier, Rev Robert Stirling D.D. Inventor of the Heat Economiser and Stirling Cycle Engine, (Chelmsford: L.A. Mair, 1995), 189 pp. See especially pp. 8-10, 17-23, 32, 37, 52-62, 67, 73-76, 79, 88-101, 107-109.

26 W. Thomson, 'Notice of Stirling's air engine' (read 21 ${ }^{\text {st }}$ April 1847), Proceedings of the Philosophical Society of Glasgow 2 (1848), pp. 169-170.

27 C.C. Lloyd, A Low Temperature Differential Stirling Engine for Power Generation (Canterbury, New Zealand: University of Canterbury MEng thesis, 2009), 118 pp.

${ }^{28}$ A. Scheyhing, Assessment of Low Temperature Electricity Production with Focus on Geothermal Energy (Göteborg: Chalmers University of Technology MSc thesis, 2012), $60 \mathrm{pp}$.

${ }^{29}$ P.T. Gaynor, R.Y. Webb \& C.C. Lloyd, 'Power generation using low temperature differential Stirling Engine technology', Proceedings of the World Geothermal Congress 2010, Bali, Indonesia, 25 $5^{\text {th }}$ 29th April (2010).

30 R. Buchanan, Practical and Descriptive Essays on the Economy of Fuel and Management of Heat, (Glasgow: Hedderwick \& Co., 1810), 253 pp. See especially Preface pp. v-vi.

${ }^{31}$ Institution of Civil Engineers, 'Obituary. James Stirling. 1800-76', Minutes of the Proceedings of the Institution of Civil Engineers 44 (1876), pp. 221-224.

32 W.J.M. Rankine, 'On the geometrical representation of the expansive action of heat, and the theory of thermo-dynamic engines', Philosophical Transactions of the Royal Society of London 144, pp. 115-175. 
33 H.B. Sutherland, 'Professor William John Macquorn Rankine', Civil Engineering (Proceedings of the Institution of Civil Engineers) 132/4 (1999), pp. 181 -187.

34 W.J.M. Rankine, Songs and Fables (London: Macmillan and Co., 1874). See especially pp. 3-6, 20-22.

35 J. MacLehose, Memoirs and Portraits of One Hundred Glasgow Men who have died during the last thirty years and in their lives did much to make the city what it now is (Glasgow: MacLehose \& Sons, 1886), 346 pp.

36 W.J.M. Rankine, 'On the stability of loose earth', Philosophical Transactions of the Royal Society 147 (1857), pp. 9-27.

$37 \mathrm{H}$. Brandl, 'Energy foundations and other thermo-active ground structures', Géotechnique 56/2 (2006), pp. 81 -122.

38 Enertime, Organic Rankine Cycle - Markets. Enertime partnership. http://archive.is/http://www.cycle-organique-rankine.com/marchesconstructeurs-reference.php, accessed $6^{\text {th }}$ July 2016.

39 International Energy Agency. Renewable Energy Essentials: Geothermal. (Paris: OECD/IEA, 2010). Available at http://www.iea.org/publications/freepublications/publication/Geothermal Essentials.pdf.

${ }^{40}$ A. Genter, X. Goerke, J.-J. Graff, N. Cuenot, G. Krall, M. Schindler \& G. Ravier, 'Current Status of the EGS Soultz Geothermal Project (France)' , Proceedings of the World Geothermal Congress 2010, Bali, Indonesia, 25 ${ }^{\text {th }}-29^{\text {th }}$ April (2010).

$41 \mathrm{~W}$. Thomson, 'On the economy of heating or cooling of buildings by means of currents of air', Proceedings of the Royal Philosophical Society Glasgow 3 (1852), pp. 269-272.

${ }^{42}$ R.V. Southwell, 'W. J. M. Rankine : A commemorative lecture', Proceedings of the Institution of Civil Engineers 5/3 (1956), pp. 177 -193.

$43 \mathrm{~W}$. Thomson, 'On the dynamical theory of heat, with numerical results deduced from Mr. Joule's equivalent of a thermal unit and M. Regnault's observations of steam', Transactions of the Royal Society of Edinburgh (March 1851). Reproduced in Mathematical and Physical Papers by Sir William Thomson, Volume 1, Article XLVIII (Cambridge: Cambridge University Press, 1882), pp. 174-332.

44 G. Cook, 'Rankine and the theory of earth pressure', Géotechnique 2/4 (1951), pp. $271-279$. 